\title{
Isolation, characterization and expression of transcription factor ScDREB2 from wild, commercial and interspecific hybrid sugarcane in salinity condition
}

\author{
Sontichai Chanprame - Tanawan Promkhlibnil - Sakulrat Suwanno - Chanakan Laksana
}

Received: 26 April 2019 / Revised: 16 May 2019 / Accepted: 27 May 2019

(C) Korean Society for Plant Biotechnology

\begin{abstract}
Dehydration Responsive Element Binding (DREB) gene is one of the essential transcription factors plants use for responding to stress conditions including salinity, drought, and cold stress. The purpose of this study was to isolate the full length and characterize the DREB gene from three different genotypes of sugarcane, wild, commercial cultivar, and interspecific hybrid sugarcane. The length of the gene, designated ScDREB was $789 \mathrm{bp}$, and coding for a putative polypeptide of 262 amino acid residues. Sequences of the gene were submitted to the GenBank database with accession numbers of KX280722.1, KX280721.1, and KX280719.1 for wild sugarcane, commercial cultivar (KPS94-13), and interspecific hybrid (Biotec2), respectively. In silico characterization indicated that the deduced polypeptide contains a putative nuclear localization signal (NLS) sequence, and a conserved AP2/ERF domain of the DREB family, at 82-140 amino residues. Based on multiple sequence alignment,
\end{abstract}

S. Chanprame

Center for Agricultural Biotechnology, Kasetsart University, Kamphaeng Saen Campus, Nakhon Pathom 73140, Thailand and The Center of Excellence on Agricultural Biotechnology, (AG-BIO/PERDO-CHE), Thailand

Department of Agronomy, Faculty of Agriculture at Kamphaeng Saen Campus, Kasetsart University, Kamphaeng Saen Campus, Nakhon Pathom 73140, Thailand

\section{T. Promkhlibnil}

Center for Agricultural Biotechnology, Kasetsart University, Kamphaeng Saen Campus, Nakhon Pathom 73140, Thailand and The Center of Excellence on Agricultural Biotechnology, (AG-BIO/PERDO-CHE), Thailand

S. Suwanno

Program in Plant Breeding, Faculty of Agriculture at Kamphaeng Saen, Kasetsart University, Kamphaeng Saen Campus, Nakhon Pathom 73140, Thailand

C. Laksana $(\square)$

Faculty of Agricultural Technology, Burapha University Sakaeo Campus, Sakaeo 27160, Thailand

e-mail: chanakanl@buu.ac.th sequences of the gene from the three sugarcane genotypes were classified in the DREB2 group. Gene expression analysis indicated, that $S C D R E B 2$ expression pattern in tested sugarcane was up-regulated by salt stress. When the plants were under $100 \mathrm{mM} \mathrm{NaCl}$ stress, relative expressions of the gene in leaves was higher than those in roots. In contrast, under 200 $\mathrm{mM} \mathrm{NaCl}$ stress, relative expressions of the gene in roots was higher than those in leaves. This is the first report on cloning the full length and characterization, of ScDREB2 gene of sugarcane. Results indicate that $S C D R E B 2$ is highly responsive to salt stress.

Keywords DREB2, Hydroponic, Sugarcane, Salt stress, Gene expression

\section{Introduction}

Salt stress is one of the most common stresses in agricultural regions worldwide. This abiotic stress adversely affects crop productivity and crop quality (Chung et al. 2012; Mahajan et al. 2013). In particular, sugarcane is affected by the salt stress condition. The plant is a moderately sensitive to salts and has a salinity threshold of $1.7 \mathrm{dS} \mathrm{m}^{-1}$ (Maas and Hoffmam 1977). There is no sugarcane cultivar presently that shows high productivity accompanied by a tolerance to salt stress (Passamani et al. 2017). Santana et al (2007) stated that sugarcane yield can be reduced by $50 \%$ in soils with electrical conductivity of $10.4 \mathrm{dS} \mathrm{m}-{ }^{1}$. Wahid et al. (1997) reported some characters of sugarcane such as waxy-coated stem, large number and area of green leaves, greater root and shoot yield, high-tillering and ratooning potential have positive correlation with salt tolerance trait. The reduction of sugarcane yield by salinity due to the restrictions in the assimilation of $\mathrm{CO}_{2}$ (Vasantha 
et al. 2010), decrease in chlorophyll content (Silva et al. 2010), reduction in turgor pressure, limited elongation and cell division (Taiz and Zeiger 2013) and accumulation of reactive oxygen species (Willadino et al. 2011). Salt accumulation in soils occurs when the quantity of salts accumulated due to irrigation water is higher than the quantity removed by the drainage water (Armas et al. 2010). Globally, data from the FAO showed that about $22 \%$ of agricultural land is saline. (Guo et al. 2014). In Thailand, the majority of the sugarcane planting areas are in the Northeast of the country (Office of the Cane and Sugar Board, 2017) where more than 2.8 million hectares are affected by salinity (Arunin 1984).

There are numerous genes associated with salt stress. However, due to the complex genome structure and inheritance, the genetic and molecular basis of biomass yield in sugarcane is still largely unknown (Singh et al. 2018). Crop tolerance to salinity is not only related to the quantity and types of salt, but also to plant genetics, as well as the external factors such as climate, soil nutritional availability, irrigation management and others (de Lira et al. 2018). Dehydration responsive element binding (DREB) gene is an important transcription factor which play a crucial role in plant abiotic stress tolerances such as salt, drought, cold and heat (Huang et al. 2018). DREB belongs to a large subfamily of the AP2/EREBP superfamily which is a large group of plant-specific transcription factors that comprises of two groups, DREB1 and DREB2 based on the sequence similarities of the AP2/EREBP domain and conservation of others specific motif present in the ERF protein (Agarwal et al. 2007; Cheng et al. 2007; Nakano et al. 2006). DREB1 is induced in drought and freezing stress. In contrast, DREB2 is induced in dehydration and high salt stress (Bouaziz et al. 2012; Zhao et al. 2007). Bouaziz et al (2012) overexpressed StDREB2 in transgenic potato plant resulting in enhanced tolerance to salt stress while the expression of the BpDREB2 gene from Broussonetia papyrifera was remarkably induced by dehydration and high-salt treatments (Sun et al. 2014). The DREB2 transcription factor has been isolated and characterized for many plant species such as wheat (TaDREB2) (Shen et al. 2003), Arabidopsis thaliana (AtDREB2) (Nakashima et al. 2006), soybean (GmDREB2) (Chen et al. 2007), and Pennisetum glaucum (PgDREB2) (Agarwal et al. 2007).

To gain more understanding of how sugarcane respond to salt stress at molecular level, cloning of the genes involve the salt stress responsive mechanism is the first step to be accomplished. The objective of this study were to isolate and do the in silico characterization of DREB2 from three sugarcane genotypes and to analyze the relative expression of the gene under difference salt concentrations and plant parts.

\section{Materials and Methods}

Plants material and growth conditions

One-inch long stalks of three sugarcane genotypes, wild sugarcane (Saccharum spontaneum L.), commercial cultivar (S. officinarum L.) cv. KPS94-13, the drought tolerant cultivar and interspecific hybrid (S. officinarum L. x S. spontaneum L.) cv. Biotec2 were used as the plant material. It has to be noted that KPS94-13 and the wild sugarcane are not the parent of Biotec2. The female parent of the interspecific hybrid was the commercial cultivar cv. Chinat 1 . Each piece of stalk contained 1 bud. They were germinated in a sand:rice ash 1:1 mixture. The 1.5 month old seedlings were transferred to and grown hydroponically in 1/10 Hoagland's nutrient solution (Hoagland and Arnon, 1950) containing 0, 100 and $200 \mathrm{mM} \mathrm{NaCl}$ (Fig. 1). Leaf and root samples were collected at $0,24,48,72,96$, and $120 \mathrm{~h}$ after salt stress for RNA extraction.

RNA extraction, cDNA synthesis and sequence analysis of $D R E B$

The total RNA was extracted from $0.1 \mathrm{~g}$ of the leaves and roots collected at various time of salt-stress by using the method described previously by Laksana and Chanprame (2015). The RNA quality was determined through PCR

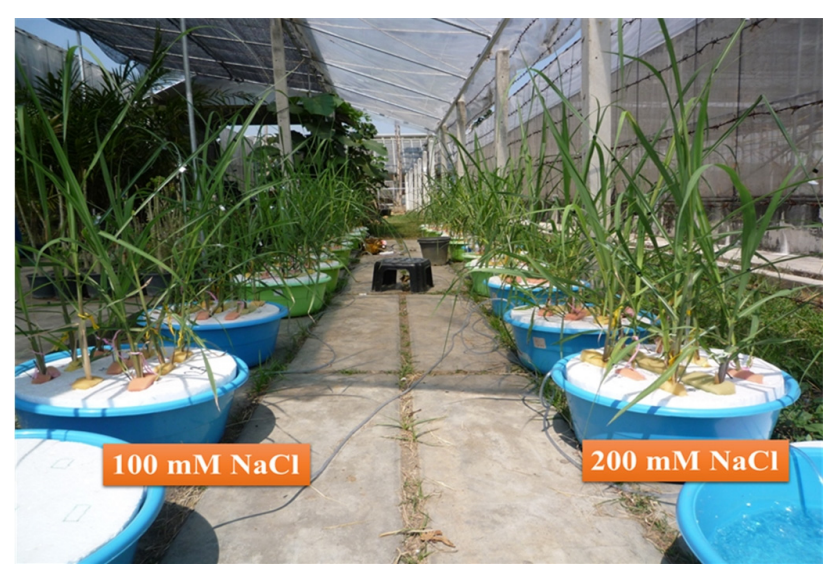

Fig. 1 The 1.5-month-old seedlings of commercial sugarcane cultivar (KPS 94-13), wild species, and interspecific hybrid were grown hydroponically in $1 / 10$ Hoagland's nutrient solution containing 0,100 , and $200 \mathrm{mM} \mathrm{NaCl}$ 
using $G A D P H$ specific primers, while the RNA quantity was determined by using a Thermo Scientific ${ }^{\mathrm{TM}}$ NanoDrop $^{\mathrm{TM}}$ One Spectrophotometer. The total RNA was used as a template for first-stranded cDNA synthesis by using a SuperScript III One-Step RT-PCR System with Platinum Taq DNA Polymerase (Invitrogen).

Amplification of the DREB gene from three genotypes of sugarcane

In order to clone the full length of the DREB gene, first strand cDNA synthesized from the total RNA extracted from the leaves of 1.5 months old seedling of the three genotypes of sugarcane was used as the template. A pair of degenerated primer (DREB-F1 5'- ATGGAGCTSGGA GACGCC -3' and DREB-RI 5'- CTAATATGMRAAAAGRCT -3 ') was designed based on the nucleotide sequences of the $D R E B$ gene of numerous plant species from the NCBI database, such as Sorghum bicolor (XM_002457244.2), Hemarthria compressa (KC203598.1), Saccharum arundinaceum (KJ670161.1), Zea mays (NM_001158997.1), Setaria italica (XM_004968237.4), and Oryza brachyantha (XM_00664 3723.2). The PCR reaction was carried out in a volume of $20 \mu \mathrm{L}$ containing $300 \mathrm{ng}$ of first-stranded cDNA template, $50 \mu \mathrm{M}$ dNTPs, $1 \mathrm{U}$ of Platinum ${ }^{\circledR}$ Taq DNA Polymerase High Fidelity (Invitrogen), $2 \mathrm{mM} \mathrm{MgCl}$, $1 \mathrm{x}$ buffer (Invitrogen), $0.125 \mu \mathrm{M}$ of each forward and reverse degenerated primer. The amplification was performed under the following conditions: initial denaturation at $95^{\circ} \mathrm{C}$ for $3 \mathrm{~min}$; then 30 cycles of denaturation at $94^{\circ} \mathrm{C}$ for $30 \mathrm{sec}$, annealing at $58^{\circ} \mathrm{C}$ for $30 \mathrm{sec}$, extension at $68^{\circ} \mathrm{C}$ for $1 \mathrm{~min}$; then a final extension at $68^{\circ} \mathrm{C}$ for $5 \mathrm{~min}$. The amplification products were resolved on a $0.7 \%(\mathrm{w} / \mathrm{v})$ agarose gel electrophoresis at $100 \mathrm{~V}$ for $25 \mathrm{~min}$.

The PCR products were cloned into $\mathrm{pGEM}^{\circledR}$-T Easy Vector (Promega), and transformed to Escherichia coli strain DH5 $a$, then sequenced at $1^{\text {st }}$ BASE Company, Malaysia. The sequences were compared with the sequences in the GenBank database (Nucleotide BLAST) (www.ncbi.nlm.nih.gov/BLAST/) using default parameters, and then translated into amino acid sequences by using Genetyx 5.0 (http://genetyx.software. informer.com/). The derived DREB amino acid sequences were aligned with the DREB amino acid sequences of other plant species by using the Clustal Omega (https://www. ebi.ac.uk/Tools/msa/clustalo/). After which, the alignment results were imported into GeneDoc 2.7 (http://genedoc. software.informer.com/2.7/) to generate a picture of multiple alignment. A phylogenetic tree was constructed based on DREB1 and DREB2 protein members by using the MEGA program (v6.0) running the Neighbor - joining algorithm.

Quantitative real time PCR (qRT-PCR) analysis

Analysis of the DREB gene expression of the three sugarcane genotypes under mimicking saline soil conditions via quantitative RT-PCR was performed. The accuracy of quantification was confirmed through normalization of the SCDREB expression to reference transcripts encoding glyceraldehydes-3phosphate dehydrogenase: GAPDH (GenBank accession no. CA254672) and eukaryotic elongation factor 1-alpha: Eef-1a (GenBank accession no. EF581011.1). Both of the reference genes were identified as suitable references gene for the normalization of the gene expression under salinity/droughttreatment in sugarcane (Guo et al. 2014). Specific primers for qRT-PCR (Table 1) were designed from conserve sequences found in the full length $D R E B$ cDNA of three sugarcane genotypes by using Primer3 ver 0.4.0 (http:// simgene.com/Primer3)

PCR reactions were performed in a total volume of 20 $\mu \mathrm{L}$ containing $500 \mathrm{ng}$ of first strand cDNA template, $1 \mathrm{x}$ SensiFAST SYBR No-ROX mix buffer (Bioline Reagent Ltd.), $0.4 \mu \mathrm{M}$ forward primer, and $0.4 \mu \mathrm{M}$ reverse primer. The amplification was performed under the following conditions: initial denaturation at $95^{\circ} \mathrm{C}$ for $30 \mathrm{sec}$; then 45 cycles of denaturation at $94^{\circ} \mathrm{C}$ for $5 \mathrm{sec}$, annealing at $58^{\circ} \mathrm{C}$ for $15 \mathrm{sec}$, and extension at $72^{\circ} \mathrm{C}$ for $10 \mathrm{sec}$ in a CFX96 Touch $^{\mathrm{TM}}$ Real-Time PCR from BIO-RAD ${ }^{\circledR}$. The expressions of the gene were compared with the control condition $(0 \mathrm{~h})$. For each sample, the reactions were carried out in three biological replicates and three technical replicates. The relative expression of each gene was calculated according to the method of $2^{\Delta \Delta \mathrm{Cq}}$ (Livak and Schmittgen 2001).

Statistical analysis

Statistical analysis was performed by using the $\mathrm{R}$ program ( $\mathrm{R}$ Core Team 2013). The results were performed as mean $\pm \mathrm{SE}$ (standard error of the mean; $n=9$ ). The differences

Table 1 Specific primers used, for real-time quantitative PCR

\begin{tabular}{ll}
\hline \multicolumn{1}{c}{ Primer name } & \multicolumn{1}{c}{ Primer sequence } \\
\hline DREB-RT F & GCTCCTTCCCTACTGCTGTG \\
DREB-RT R & CACTAGATGCCAGCAACGAA \\
Sc-GADPH F & CACGGCCACTGGAAGCA \\
Sc-GADPH R & TCCTCAGGGTTCCTGATGCC \\
Sc-Eef-1a F & TTTCACACTTGGAGTGAAGCAGAT \\
Sc-Eef-1a R & GACTTCCTTCACAATCTCATCATAA \\
\hline
\end{tabular}


in the data were compared by ANOVA followed by using the Duncan's multiple range test. The differences were investigated significant at $p<0.05$.

\section{Results}

Cloning of full length $D R E B$ cDNA from three genotypes of sugarcane

The full length of the $D R E B$ gene from three genotypes of sugarcane were cloned using a pair of degenerated primer. The sequences of the putative $D R E B$ gene exhibited one open reading frame (ORF) composed of $789 \mathrm{bp}$ and encoded a putative polypeptide of 262 amino acid residues. The predicted protein had a calculated molecular mass of $28.6 \mathrm{kDa}$ and a theoretical isoelectrics point of 5.42. A putative nuclear localization signal (NLS) sequence was detected by using NLSstradamus (http://www.moseslab.csb.utoronto. ca/NLStradamus/) (Ba et al., 2009). The deduced protein contained a conserved AP2/ERF domain of the DREB family at 82-140 amino residues (Fig. 2). The sequence show a high similarity to the DREB2 gene from many plant species including Sorghum bicolor (XM_002457244.2; 94\%), Hemarthria compressa (KC203598.1; 96\%), Saccharum arundinaceum (KJ670161.1; 97\%), Zea mays (NM 001158997.1;

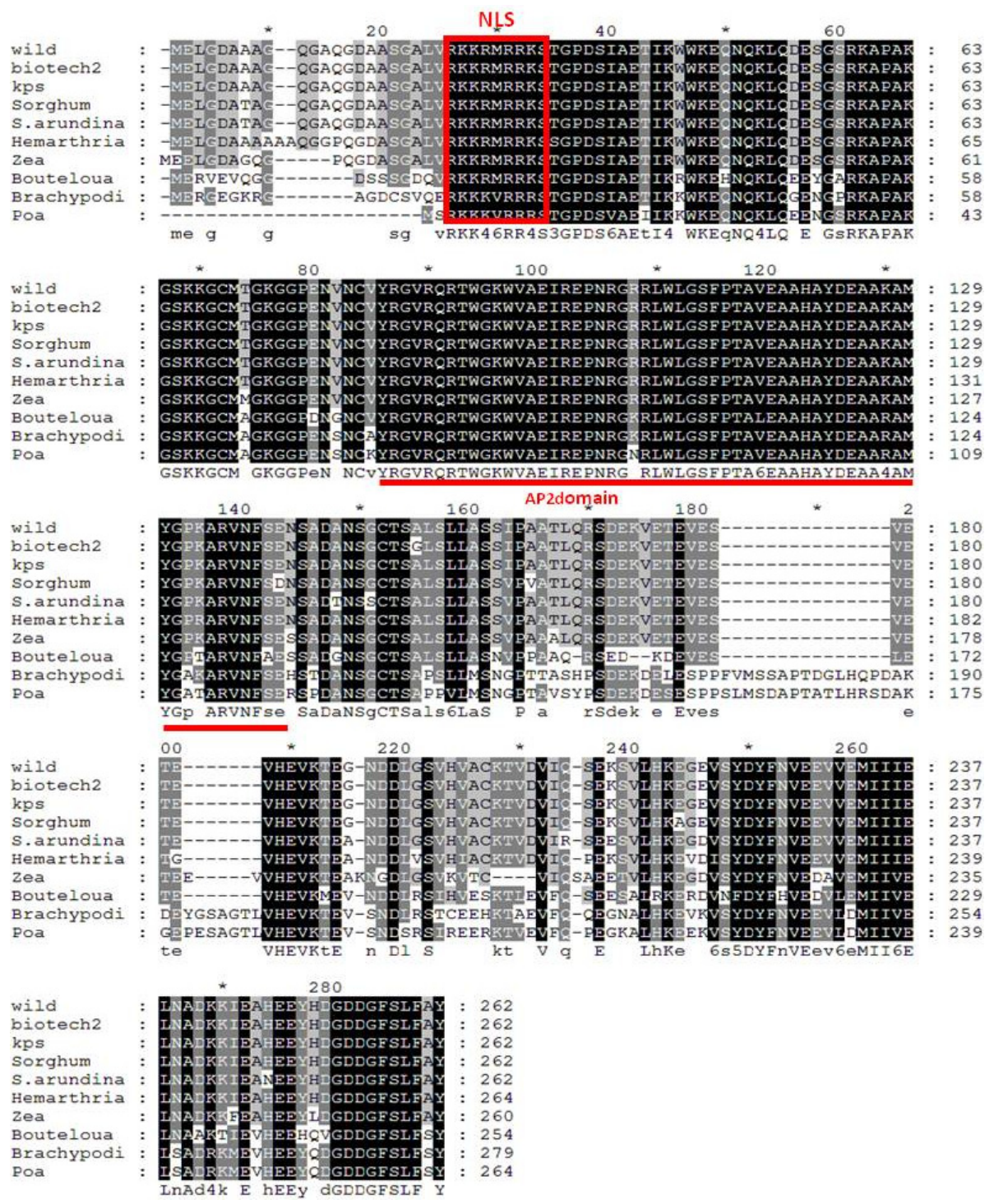

Fig. 2 Multiple alignment of the deduced amino acid sequence of ScDREB2 from wild sugarcane, commercial cultivar cv. KPS 94-13, and interspecific hybrid cv.Biotech2, Sorghum bicolor (XP_002457289.1) Saccharum arundinaceum (AIU40168.1), Hemarthria compressa (AGG20202.1), Setaria italica (P_001296982.1), Zea mays (NP_001152469.1), Bouteloua dactyloides (ABP52086.1), Dichanthelium oligosanthes (OEL14136.1), Brachypodium distachyon (XP_024314715.1), Oryza sativa Indica (EAY72665.1), and Poa pratensis (AAS59530.1) 


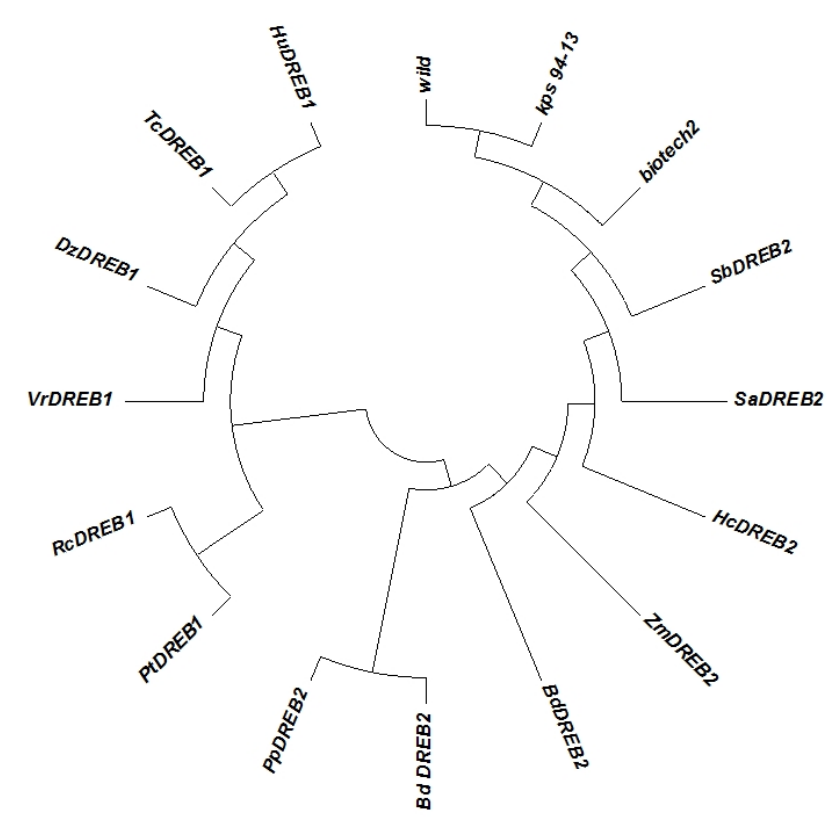

Fig. 3 Phylogenetic tree of ScDREB2 protein from wild sugarcane (wild), commercial cultivar (KPS94-13), interspecific hybrid (Biotech 2), and other different plant species. It was constructed based on deduced amino acid sequences using MEGA 5.0 software. GenBank accession numbers of amino acid sequences used: SbDREB2 Sorghum bicolor (XP_002457289.1), SaDREB2 Saccharum arundinaceum (AIU40168.1), HcDREB2 Hemarthria compressa (AGG20202.1), Setaria italica (P_001296982.1), ZmDREB2 Zea mays (NP 001152469.1), BdDREB2 Bouteloua dactyloides (ABP52086.1), Bd_DREB2 Brachypodium distachyon (XP_024314715.1), PpDREB2 Poa pratensis (AAS59530.1), TcDREB1Theobroma cacao (XP_007015927.2), HuDREB1 Herrania umbratica (XP_021277951.1), DzDREB1 Durio zibethinus (XP 022730283.1), VrDREB1 Vitis rubra (AIL00538.1), PtDREB $\overline{1}$ Populus trichocarpa (XP_024455149.1), RcDREB1 Ricinus communis (XP_002532187.1)

88\%), Setaria italica (XM_004968237.4; 86\%), and Oryza brachyantha (XM_006643723.2; 79\%). Based on this similarity, we named it SCDREB2. The sequence data from the three genotypes of sugarcane have been submitted to the NCBI database. The accession number of ScDREB2 from wild sugarcane, commercial cultivar (cv. KPS94-13) and interspecific hybrid (cv. Biotec2) are KX280722.1, KX280 721.1 and KX280719.1, respectively. The phylogenetic analysis of the deduced ScDREB protein from the three sugarcane genotypes showed some genetic distance among them. The protein from wild sugarcane was close related to that of KPS94-13 while the protein from the interspecific hybrid showed more distance to the early mentioned protein. However, these proteins were very similar to DREB2 protein from Sorghum bicolor (SbDREB2) and Saccharum arundinaceum (SaDREB2) (Fig. 3).
Expression analysis of SCDREB2 in the leaves and roots of the three sugarcane genotypes under different salt stress conditions

The analysis of the SCDREB2 expression was done under different $\mathrm{NaCl}$-stress levels using semi-quantitative PCR. The sugarcane seedlings were subjected to $1 / 10$ Hoagland solution together with 100 and $200 \mathrm{mM} \mathrm{NaCl}$ for 0,24 , 48, 72, 96, and $120 \mathrm{~h}$. Under $100 \mathrm{mM} \mathrm{NaCl}$-stress condition, relative expression of SCDREB2 in the leaf of KPS 94-13 reached the highest level at $72 \mathrm{~h}$ of stress and decreased sharply later on. When compared with the control $(0 \mathrm{~h})$ this was about a 50 -fold increase. For the wild species and interspecific hybrid (Biotech2) at 24-72 h of stress the relative expressions of the gene also increased but at lower levels than KPS 94-13. At 96 and $120 \mathrm{~h}$ of stress the wild sugarcane and Biotech2 showed higher expression level than KPS 94-13 (Fig. 4A). In the root, KPS 94-13 had the highest relative expression at $24 \mathrm{~h}$ of stress at 24-fold higher that the control and decreased sharply later on. Whereas the expression of the gene of wild sugarcane gradually increased starting at $24 \mathrm{~h}$ and reached the highest expression level at $96 \mathrm{~h}$ of stress (Fig. 4B). For the 200 $\mathrm{mM} \mathrm{NaCl}$ condition, in the expression of the gene in the leaf KPS 94-13 was the highest at $24 \mathrm{~h}$ of stress with about 63 -fold higher than the control and then it gradually decreased, whereas the wild sugarcane and Biotech2 were substantially increased (Fig. 4C). In the root the expression of SCDREB2 reached the highest induction of 120-fold of the control at $24 \mathrm{~h}$. The expression of the gene in Biotech2 reached the highest level of about 80-fold of the control at $72 \mathrm{~h}$ of stress, while a lower and slowly increasing expression level was found in the wild sugarcane (Fig. 4D). The results indicated that under salt stress the SCDREB2 expressions in all tested genotypes were up-regulated when compared with the control. When compared the expression level of the gene in leaf or root at $100 \mathrm{mM} \mathrm{NaCl}$ with $200 \mathrm{mM} \mathrm{NaCl}$ it was found that the $200 \mathrm{mM} \mathrm{NaCl}$ induced higher expressions of the gene than those of the $100 \mathrm{mM}$ $\mathrm{NaCl}$. The results suggested that the higher level of salt stress could induce more expression of the SCDREB2 than lower level of stress did. When compared the expression level of the gene in leaf to root it revealed that the tendency of the expression level of the gene in leaf was higher than in root. This inferred that this transcription factor might be involved in the expression of more genes in leaves than the genes in roots. The pattern of gene expression in KPS 94-13 was difference from wild and interspecific hybrid. The expression of ScDREB2 in KPS 94-13 increased 

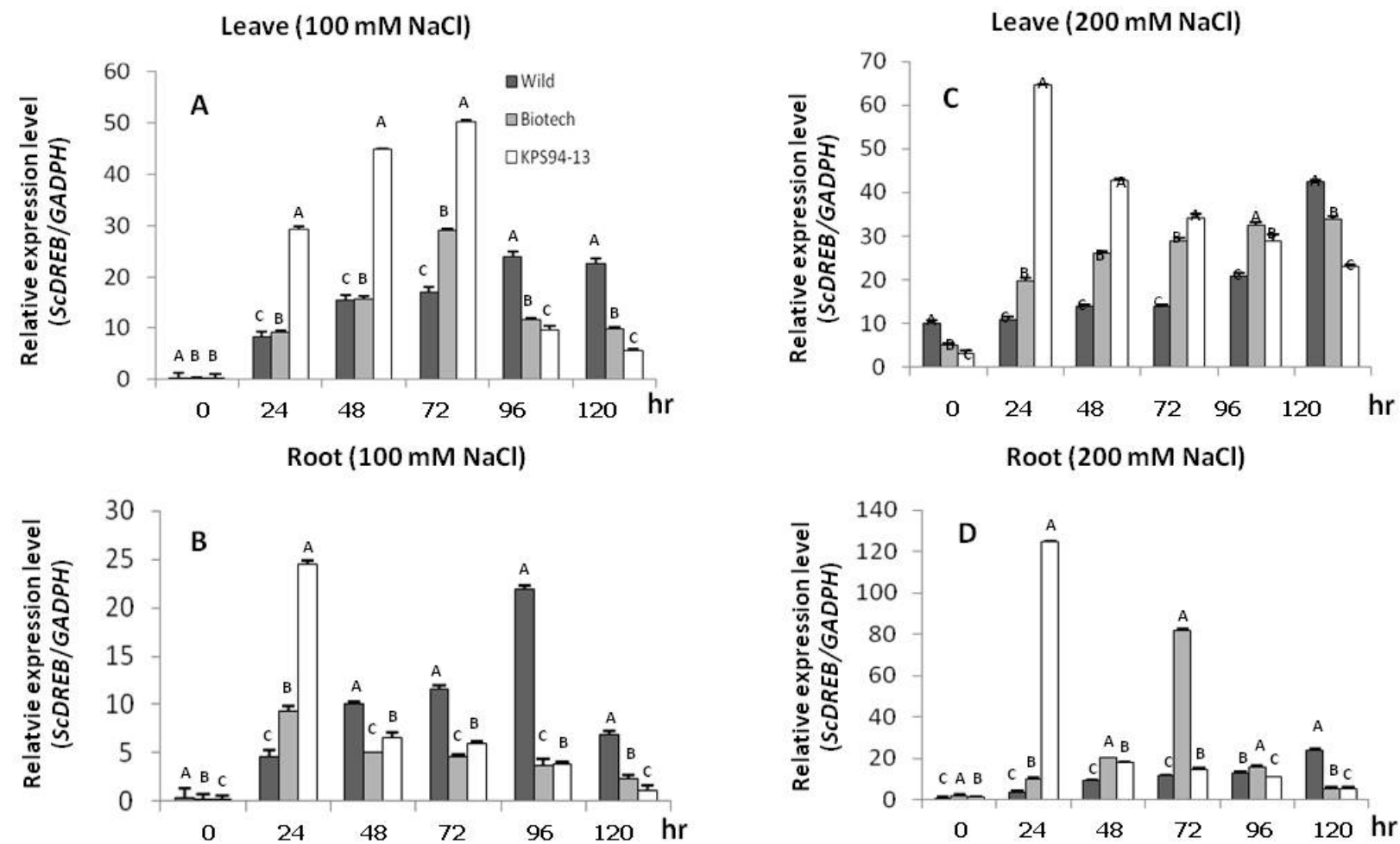

Fig. 4 Relative expression level of ScDREB2 in leaves (A, C) and roots (B, D) of wild sugarcane, interspecific hybrid (Biotec2), and commercial cultivar (KPS 94-13) subjected to $100 \mathrm{mM} \mathrm{NaCl}$ (A and B) and $200 \mathrm{mM} \mathrm{NaCl}$ (C and D) for 0-120 hours. Data are means $\pm \mathrm{SE}$ of the three biological replicates. Different letters on the boxes indicate significant differences between genotype, under the same period of stress at $P<0.05$ according to DMRT

immediately after receiving salt stress and then decreased when the stress was prolonged while the expressions of the gene in wild and interspecific hybrid were gradually increased when the times of stress were extended. These results indicated that the commercial sugarcane responded to salt stress faster than the wild and interspecific hybrid sugarcane. However, the physiological study of these sugarcane genotypes under salt stress in combination with the expression pattern of the SCDREB2 should be done to confirm the relationship of the gene expression pattern and the sensitivity or tolerance to salt stress.

\section{Discussion}

Salt stress is a seriously problem on the growth and production of most economic crops. Understanding the adaptive mechanisms to salinity stress is an important prerequisite for crop improvement and sustainable production. Physiological traits and biochemical processes that plants use for copping salt stress are developed from gene expressions. Transcription factor is one of the important factors controlling the transcription level of the genes. DREB is one of the transcription factors that participates in plant response to salt stress in several plant species and is an important prerequisite for use of stress-inducible gene in crop improvement (Sun et al. 2014). Numerous studies have demonstrated that DREB protein is involved in the improvement of stress tolerance of plants. DREB belongs to a subfamily of the AP2/EREBP superfamily which comprises of two groups, DREB1 and DREB2 which are major regulators and functions of DREBs (Agarwal et al. 2007; Nakano et al. 2006). DREB1 is induced by cold while DREB2 is induced by dehydration and high salinity (Liu et al. 1998). DREB2A is a salinity-inducible transcription factor and have been isolated and characterized from many plant species such as Sophora moorcroftiana (Yao et al. 2016), rice (Cui et al. 2011), Buchloe dactyloides (Zhang 2014), soybean (Chen et al. 2007), Populus euphratica (Chen et al. 2009), potato (Bouaziz et al. 2012) and paper mulberry (Sun et al. 2018). However, there has been no publication on the cloning and characterization of the $D R E B 2$ gene in sugarcane under salt stress. This is the first report describing the cloning and characterization of $S c D R E B 2$ gene in sugarcane. In this study, we described the identification and characterization of SCDREB2 from the commercial sugarcane cultivar cv. KPS 94-13, wild sugarcane and interspecific hybrid sugarcane cv. Biotech2. 
ScDREB2 was successfully isolated by using the PCR technique with primers designed from the $D R E B$ gene of various plants species. The result of phylogenetic analysis indicated that the ScDREB belonged to the DREB2 group and was closely related with DREB2 from sorghum (Fig. 3) because the sugarcane and sorghum genomes are mostly collinear in the genic regions (Wang et al. 2010). The sequence of ScDREB2 contains NLS and AP2/ERF domain position. The entrance of DREB proteins is arbitrated to NLS. The transcription factor having no NLSs enter into the nucleus through protein-protein interaction with the transcription factors that have NLSs (Stockinger et al. 1997). The AP2/ERF family is a large group of plant-specific transcription factors that include four major subfamilies: AP2, RAV, ERF and DREBs (Sakuma et al. 2002). DREB is a major transcription factor involved in plant abiotic stress response by regulating gene expression via the cis-acting dehydration-responsive element/C-repeat (DRE/ CRT) element. (Yamaguchi-Shinozaki and Shinozaki 2006). The AP2 domain of ScDREB2 consists of approximately 60 amino acid residues which is the same as the AP2/ERF domain reported by Weigel (1995). Furthermore, the sequences of the AP2 domain show high conservation among the 3 genotypes of sugarcane and also among other plant species (Fig. 1). This indicates the important role of this domains as a DNAbinding domain (Weigel 1995).

The relative expression study indicated that the expression of SCDREB2 was up-regulated under salt stress both in leaf and root when compared with the normal condition. Similar results were also observed in BdDREB2 of buffalograss (Zhang et al. 2014), GmDREB2 of soybean (Chen et al. 2007), StDREB2 of potato (Bouaziz et al. 2012) and BpDREB2 of Broussonetia papyrifera (Sun et al. 2014). Under 100 $\mathrm{mM}$ and $200 \mathrm{mM} \mathrm{NaCl}$ conditions, the expression of SCDREB2 in KPS94-13 was high in the early period of stress and then sharply decreased the next day, whereas the expressions of the gene in wild sugarcane gradually increased and reached the highest level at late period of stress (96-120 h after stress induction). This phenomenon might correlate with the characteristic of wild species of plant that more adaptive to unfavorable conditions than the commercial cultivar, in this case when salt stress was prolonged. In contrast, the expression pattern of the gene in wild sugarcane was similar to the expression pattern of the interspecific hybrid. This may be due to the genetic back ground concerning salt stress responsive traits of the interspecific hybrid derived from wild species of sugarcane. As mentioned in the material and method section that the commercial cultivar and the wild sugarcane were not the parent of the interspecific hybrid used in this study. So, it is very difficult to elucidate the relationship of the expression patterns among them.

The relative expressions of SCDREB2 in root and leaf of sugarcane subjected to $200 \mathrm{mM} \mathrm{NaCl}$ were higher than those of the $100 \mathrm{mM} \mathrm{NaCl}$. This result is very similar with the expression of PeDREB2 in Populus euphratica which showed a higher expression in high salt treatment (300 mM NaCl) (Chen et al. 2009). Yang et al (2017) also reported the expression of ThDREB from Tamarix hispida was highly induced by $\mathrm{NaCl}$ and the highest expression level was 369.2-fold over the control plant. The expression level of the gene in leaf was higher than that in root at both concentrations of $\mathrm{NaCl}$. This result is accordant with Laksana and Chanprame (2017) and Kaewjiw et al (2018) who reported that MIPS and SOS1 gene in leaves of sugarcane expressed at higher levels than those of the roots in salt stress condition. These two genes also involve in the salt responsiveness mechanism and somehow the transcription factor SCDREB2 may regulate the expression of them. These evidences point out that SCDREB2 is a salt stress responsive gene and it might play a crucial role in providing tolerance to multiple stresses. However, we found some variations in the nucleotides among the sugarcane studied. These variations may or may not relate to different patterns of gene expression in salt stress condition. These variations may relate to the difference isoforms of the gene and protein as well. To gain more understanding and to confirm the role of this gene relates to salt tolerance, we will produce transgenic tobacco containing different ScDREB2. We will determine and compare the expression levels of the transgenes and the degree of salt tolerance of the transgenic tobacco. When the correlation between the expression pattern and salt tolerance is proven this will also be a benefit for the development of a molecular marker for selection of salt tolerant sugarcane in the breeding program.

\section{Conclusion}

Salt stress reduces the potential yield in crop plants including sugarcane. The development of crops that are better adapted to salt stresses is important for sustainable production. In this work, we cloned and characterized the SCDREB2 from three different genotypes of sugarcane subjected to salt stress. The deduced amino acid sequence of ScDREB2 had a strong similarity to DREB2 of many other plant species and contained the AP2 domain which is an important site for DNA binding. The expression of ScDREB gene in 
sugarcane showed up-regulation pattern when compared with the control plant in salt stress condition. Base on the result, we concluded that $S C D R E B 2$ is an important transcription factor that regulated under salt stress and has considerable potential for improving salt stress tolerance in sugarcane.

\section{Acknowledgement}

This work was financially supported by a Research Grant of Burapha University through the National Research Council of Thailand (Grant No. 8/2560). This work was also supported by the Thailand Research Fund and was partially supported by the Center for Agricultural Biotechnology and Center of Excellence on Agricultural Biotechnology, Science and Technology Postgraduate Education and Research Development Office, the Commission on Higher Education, the Ministry of Education (AG-BIO/ PERDO-CHE) Thailand. Acknowledgement is also extended to the Department of Agronomy, Faculty of Agriculture at Kamphaeng Saen, Kasetsart University.

Conflict of interest The authors declare that they have no conflict of interest.

\section{References}

Agarwal P, Agarwal PK, Nair S, Sopory SK, Reddy MK (2007) Stress-inducible DREB2A transcription factor from Pennisetum glaucum is a phosphoprotein and its phosphorylation negatively regulates its DNA-binding activity. Mol Genet Genomics 277:189-98

Armas C, Padilla FM, Pugnaire FI, Jackson RB (2010) Hydraulic lift and tolerance to salinity of semiarid species: Consequences for species interactions. Oecologia 162:11-21

Arunin S (1984) Characteristics and management of salt affected soil in the Northeast of Thailand, p.336-351. In: Ecology and Management of Problem Soils in Asia, Food and Fertilizer Technology Center for the Asian and Pacific Region, Taipei, Rep of China

Ba ANN, Pogoutse A, Provart N, Moses AM (2009) NLStradamus: A simple hidden markov model for nuclear localization signal prediction. BMC Bioinform 10(1):202

Bouaziz D, Pirrello J, Amor HB, Hammami A, Charfeddine M, Dhieb A, Bouzayen M, Gargouri-Bouzid R (2012) Ectopic expression of dehydration responsive element binding proteins (StDREB2) confers higher tolerance to salt stress in potato. Plant Physiol Biochem 60:98-108

Chen J, Xia X, Yin W (2009) Expression profiling and functional characterization of a DREB2-type gene from Populus euphratica.
Biochem Biophys Res Commun 378:483-487

Chen M, Wang Q-Y, Cheng X-G, Xu Z-S, Li L-C, Ye X-G, Xia L-Q, Ma Y-Z (2007) GmDREB2, a soybean DRE-binding transcription factor, conferred drought and high-salt tolerance in transgenic plants. Biochem Biophys Res Commun 353: 299-305

Chung E, Kim K, Lee JH (2012) Molecular cloning and characterization of a soybean $G m M B Y 184$ induce by abiotic stress. J Plant Bitechnol 39:175-181

Cui M, Zhang W, Zhang Q, Xua Z, Zhu Z, Duanb F, Wu R (2011) Induced over-expression of the transcription factor OsDREB2A improves drought tolerance in rice. Plant Physiol Biochem 49: 1384-1391

de Lira RM, Silva ÊF de F e Neto, Simões DE, Santos Júnio JA, Lima BL de C, da Silva JS (2018) Growth and yield of sugarcane irrigated with brackish water and leaching fractions. Agriambi 22:170-175

Guo J, Ling H, Wu Q, Xu L, Que Y (2014) The choice of reference genes for assessing gene expression in sugarcane under salinity and drought stresses. Sci Rep 4: 7042 DOI: 101038/srep07042

Hoagland, DR, Arnon DI. (1950) The Water Culture Method for Growing Plants without Soil. Circular 347, University of California, College of Agriculture, Berkeley, USA

Huang L, Wang Y, Wang W, Zhao X, Qin Q, Sun F, Hu F, Zhao Y, $\mathrm{Li}$ Z, Fu B, Li Z (2018) Characterization of transcription factor gene $O s D R A P 1$ conferring drought tolerance in rice. Front Plant Sci 9:94 DOI: 103389/fpls201800094

Kaewjiw N, Laksana C, Chanprame S (2018) Cloning and identification of salt overly sensitive ( $S O S 1)$ gene of sugarcane. Int J Agric Biol 20:1569-1574

Laksana C, Chanprame S (2015) A simple and rapid method for RNA extraction from young and mature leaves of oil palm (Elaeis guineensis Jacq). ISSAAS 21:96-106

Laksana C, Chanprame S (2017) Partial cloning and expression of ScBADH and ScMIPS gene in wild and cultivated sugarcane under mimicking saline soil conditions. ISSAAS 23:183-192

Liu Q, Kasuga M, Sakuma Y, Abe H, Miura S, YamaguchiShinozaki K, Shinozaki K (1998) Two transcription factors, DREB1 and DREB2, with an EREBP/AP2 DNA binding domain separate two cellular signal transduction pathways in drought- and low-temperature-responsive gene expression, respectively, in Arabidopsis. Plant Cell 10:1391-1406

Livak, KJ, Schmittgen TD (2001) Analysis of relative gene expression data using real-time quantitative PCR and the 2(-Delta Delta C(T)) method. Methods 25:402-408

Maas EV, Hoffman GJ (1977) Crop salt tolerance - current assessment. J Irrig Drain Eng 103:115-134

Mahajan, ST, Naik RM, Dalvi US (2013) Assessment of biochemical markers in differentiating sugarcane genotypes for salt tolerance. Sugar Tech 15: 116-121

Nakashima K, Fujita Y, Katsura K, Maruyama K, Narusaka Y, Seki M, Shinozaki K, Yamaguchi-Shinozaki K (2006) Transcriptional regulation of $\mathrm{ABI} 3-$ and $\mathrm{ABA}-$ responsive genes including $R D 29 B$ and $R D 29 A$ in seeds, germinating embryos, and seedlings of Arabidopsis. Plant Mol Biol 
60:51-68

Nakano, T, Suzuki K, Fujimura T, Shinshi H(2006) Genome-wide analysis of the ERF gene family in Arabidopsis and rice. Plant Physiol 140:411-432

Office of the Cane and Sugar Board (2017) Report on Sugarcane Planting Areas in 2016/17 Planting Crop Year. 127p

Passamani LZ, Barbosa RR, Reis RS, Heringer AS, Rangel PL, Santa-Catarina C, Grativol C, Veiga CFM, Souza-Filho GA, Silveira V (2017) Salt stress induces changes in the proteomic profile of micropropagated sugarcane shoots. PLOS ONE 12: $1-21$

R Core Team (2013) R: A language and environment for statistical computing R. Foundation for Statistical Computing. Vienna, Austria. 409p

Sakuma Y, Liu Q, Dubouzet JG, Abe H, Shinozaki K, Yamaguchi-Shinozaki K (2002) DNA-binding specificity of the ERF/AP2 domain of Arabidopsis DREBs, transcription factors involved in dehydration- and cold-inducible gene expression. Biochem Biophys Res Commun 290:998-1009

Santana MJ, Carvalho JA, Souza KJ, Sousa AMG, Vasconcelos CL, Bastos Andrade LA (2007) Effects of irrigation water salinity upon the sprouting and initial development of sugarcane (Saccharum spp) and on soils with different textural levels. AgroTech J 31:1470-1476

Shen YG, Zhang WK, He SJ, Zhang JS, Liu Q, Chen SY (2003) An EREBP/AP2-type protein in Triticum aestivum was a DREbinding transcription factor induced by cold, dehydration and ABA stress. Theor Appl Genet 106:923-930

Silva EN, Ribeiro RV, Ferreira-Silva SL, Viégas RA, Silveira JAG (2010) Comparative effects of salinity and water stress on photosynthesis, water relations and growth of Jatropha curcas plants. J Arid Environ 74:1130-1137

Singh R, Jones T, Wai CM, Jifon J, Nagai C, Ming R, Yu Q (2018) Transcriptomic analysis of transgressive segregants revealed the central role of photosynthetic capacity and efficiency in biomass accumulation in sugarcane. Sci Rep 8: 1-10

Stockinger EJ, Gilmour SJ, Thomashow MF (1997) Arabidopsis thaliana CBF1 encodes an AP2 domain containing transcriptional activator that binds to the $\mathrm{C}$ repeat/DRE, a cis acting DNA regulatory element that stimulates transcription in response to low temperature and water deficit. Proc Natl
Acad Sci USA 94:1035-1040

Sun J, Peng X, Fan W, Tang M, Liua J, Shen S (2018) Functional analysis of $B p D R E B 2$ gene involved in salt and drought response from a woody plant. Broussonetia papyrifera. Gene 535:140-149

Taiz L, Zeiger E (2013) Fisiologia Vegetal. $5^{\mathrm{a}}$ ed. Porto Alegre, ArtMed. 954p

Vasantha S, Venkataramana S, Rao PNG, Gomathi R (2010) Long term salinity effect on growth, photosynthesis and osmotic characteristics in sugar cane. Sugar Tech 12:5-8

Wahid A, Rao A, Rasul E (1997) Identification of salt tolerance traits in sugarcane lines. Field Crops Res 54:9-17

Wang J, Roe B, Macmil S, Yu Q, Murray JE, Tang H, Chen C, Najar F, Wiley G, Bowers J, van Sluys MA, Rokhsar DS, Hudson ME, Moose SP, Paterson AH, Ming R (2010) Microcollinearity between autopolyploid sugarcane and diploid sorghum genomes. BMC Genomics 11:261

Weigel D (1995) The APETALA2 domain is related to a novel type of DNA binding domain. Plant Cell 7:388-389

Willadino L, OliveiraFilho RA, Silva EA, GouveiaNeto AS, Camara TR (2011) Estresse salino em duas variedades de cana-de-açúcar: enzimas do sistema antioxidativo e fluorescência da clorofila. Revis Ciência Agron 42:417-422

Yamaguchi-Shinozaki K, Shinozaki K (2006) Transcriptional regulatory networks in cellular responses and tolerance to dehydration and cold stresses. Annu Rev Plant Biol 57: 781-803

Yang G, Yu L, Zhang K, Zhao Y, Guo Y, Gao C (2017) A ThDREB gene from Tamarix hispida improved the salt and drought tolerance of transgenic tobacco and T. hispida. Plant Physiol Biochem 113:187-197

Yao W, Yaru F, Zhang Y, Li HE (2016) Cloning of four DREB genes from Tibetan Sophora moorcroftiana and analysis of their expression during abiotic stress. J Forest Res 27:675-683

Zhao J, Ren W, Zhi D, Wang L, Xia G (2007) Arabidopsis $D R E B 1 A / C B F 3$ bestowed transgenic tall fescue increased tolerance to drought stress. Plant Cell Rep 26:1521-1528

Zhang P, Yang P, Zhang Z, Han B, Wang W, Wang Y, Cao Y, Hu $\mathrm{T}$ (2014) Isolation and characterization of a buffalograss (Buchloe dactyloides) dehydration responsive element binding transcription factor, BdDREB2. Gene 536:123-128 